Contemporary Research in Education and English Language Teaching

ISSN: 2641-0230

Vol. 3, No. 2, pp. 21-30

2021

Publisher: Learning Gate

DOI: 10.33094/26410230.2021.32.21.30

(C) 2021 by the authors; licensee Learning Gate

\title{
Error Analysis in Descriptive English Writing among Undergraduates in Hunan City University
}

\author{
Chen Qian \\ PhD Student, Faculty of Education and Liberal Studies, City University Malaysia, Petaling Jaya, Selangor, Malaysia. \\ Email:28527608@qq.com \\ Subadrah Madhawa Nair* \\ Lecturer, Faculty of Education and Liberal Studies, City University Malaysia, Petaling Jaya, Selangor, Malaysia. \\ Email:subadrah.nair@,city.edu.my (*Corresponding Author)
}

Received: 4 June 202 1; Revised: 9 July 2021; Accepted: 13 August 202 1; Published: 6 September 2021

\begin{abstract}
In this age of globalization, EFL writing skills are essential for Chinese undergraduates, especially in the areas of communication, education and business cooperation. The objective of this study is to study and analyze EFL descriptive writing errors among Chinese undergraduates, according to gender and faculty of study. Descriptive research design was employed in this study. The undergraduate students in the study were given a descriptive writing test and their essays were marked by a lecturer using rubric provided by the researchers. The sample of the study consisted of 400 Chinese undergraduate students (200 males and 200 females,) from Hunan City University in Hunan Province, China. Stratified random sampling was employed in selecting the samples. Students' errors in EFL writing were analyzed based on Corder's error analysis and James's classification of errors. The findings from quantitative data revealed that male students made significantly more errors than female students in their overall writing, mechanical, coherence and cohesion, grammar, lexical and sentence structures. There is also significant difference in the mean errors among students from the four faculties. Moreover, the results indicated that the students from the faculties of Education Management and Chinese Language Studies (social sciences) performed better than the students from the other faculties. In terms of pedagogical implications, the findings suggest that further research should be carried out to minimize male students' errors in their writing skills as well as the students from the Information Technology and Civil Engineering faculties.
\end{abstract}

Keywords: Error analysis, Descriptive writing, Gender, Undergraduates, Faculty, EFL, Chinese undergraduates.

\section{Introduction}

\subsection{Background of the Study}

In the process of language learning, language learners inevitably commit errors. These errors convey information and messages about the process of language learning, learners' language competence and the roots of those errors. Analyzing learners' errors has become an essential requirement for answering some questions and proposing solutions to different aspects of language teaching. Therefore, error analysis (EA) as a diagnostic tool is a great help to the field of language teaching and learning (Boroomand \& Rostami Abusaeedi, 2013).

In the age of globalization, good English writing skills are essential for communication, education and business cooperation (Kelly-Riley, 2015). The essays written by ESL or EFL students who learn English as a second or foreign language usually contain different types of errors. In other words, 
acquiring English writing skills has always been a challenge for English learners. As an important skill, writing needs to receive more attention. Therefore, by analyzing the writing errors committed by English learners, teachers can know the sources and types of these errors, so as to adopt more effective teaching methods and strategies and to improve the English writing ability of English learners (Hart Research Associates, 2015).

As a result of researchers' interest in the issue of gender differences from different aspects, it has become the subject of many studies for many years. Gender is an influential variable in nearly all social phenomena, including language, so it can be a considerable source of variation among language learners and teachers must consider its impact on language learning.

Gender differences have been the subject of many studies over the years. As a result, researchers have been interested in gender differences in many research issues. Gender is an influential variable in teaching and learning language (Corona et al., 2017). Therefore, it can be a considerable source of variation among language learners, and teachers must consider its influence on language learning (Voyer \& Voyer, 2014).

Khurshid and Mahmood (2012) indicated that educational discipline can influence differences in learning outcome and they found that learning styles vary between students from different faculties. As this variable has been found to affect learning, it follows that students of social and natural sciences should receive language instruction differently.

There are only a few studies which have been conducted on aspects of gender differences or faculty differences in EFL learners' writing skills in the field of error analysis. Following error analysis procedures, this study has taken college English learners from Hunan City University as the research subjects and analyzes the errors they make in the writing process, and compares the writing errors according to gender and faculty. Moreover, the results of this research are expected to help improve teaching and learning processes when an EFL teacher teaches students from different faculties English writing skills.

\subsection{Research Questions}

1. Is there a significant difference in the total number of writing errors in descriptive writing among Chinese undergraduates according to gender?

2. Is there a significant difference in the number of mechanical errors in descriptive writing according to gender?

3. Is there a significant difference in the number of coherence and cohesion errors in descriptive writing according to gender?

4. Is there a significant difference in the number of grammatical errors in descriptive writing according to gender?

5. Is there a significant difference in the number of lexical errors in descriptive writing according to gender?

6. Is there a significant difference in the number of structural errors in descriptive writing according to gender?

7. Is there a significant difference in the total number of writing errors in descriptive writing among Chinese undergraduates according to faculty?

\section{Review of Literature}

According to Divsar and Heydari (2017), writing skills require more effort to master than other language skills because writers must compose sentences and be knowledgeable of appropriate vocabulary to convey his/her intended meaning in an organized and coherent format. Due to the nature of writing, which requires a range of vocabulary, syntax and morphology, EFL learners often make errors in writing (Cumm ing, 2003). Students' writing errors stem from their inability to generate ideas, organize discourse, control sentence structures, choose appropriate vocabulary, and use effective styles (Mohammed, 2014). 


\subsection{Error Analysis}

Generally speaking, error analysis is an approach which became a theory in the 1960 s with Corder (1967) The Significance of Learner's Errors. According to Corder (1981), error analysis is a kind of bilingual comparison between learners' inter language and target language. In short, error analysis is a process of collecting learners' language samples, identifying errors in the samples, describing these errors, classifying them according to the assumed reasons and assessing their seriousness (James, 2013).

Christine (2016) thinks that error analysis can help to enhance teaching and learning of a second language or a foreign language through investigating errors made by learners. Therefore, error analysis might be one of the ways to enhance the target students' English Language proficiency. According to Zafar (2016), only by identifying errors students can minimize them. He also pointed out that classifying and analyzing errors can show students and teachers which errors occur more frequently and why they occur.

\subsection{Classification of Errors}

According to James (1998), linguists are always trying to categorize the errors that language learners make and this is the most helpful way for applied linguists to find out the problems. Dulay, Burt, and Krashen (1982) pointed out that when learners specially and systematically changed the surface structure of the target language, errors would occur. Therefore, whatever the form and type of errors, they represent the damage level of the target language.

Richards and Schmidt (2002) classified errors into two categories: inter lingual errors and intra lingual errors, referring respectively to the negative effects of the speaker's native language and the target language itself. Christine (2016) adapted categorization of errors by both James (1998) and Dulay et al. (1982) and categorized the errors into three levels: first, substance (mechanics); second, text (grammar and lexical errors) and third, discourse (pragmatic errors and coherence). In this study, errors in substance and text and discourse levels will be identified.

\subsection{Gender and Error Analysis}

Many studies on the existence and nature of differences between men and women from different perspectives have been carried out, and language as a social phenomenon hasn't been an exception. Men and women tend to function differently in their brain and language functions and these functions may be more organized in women (Dingwall (1998) cited in Chiu (2008)). Montenegro and Jankowski (2017) claimed that females are better than males in first and second language acquisition. Gray (2013) reported higher mean scores for females than males in a Japanese language class. A study by Salem (2006) showed significant differences between males and females in their use of memory and cognitive and compensation strategies, and the results were in favor of females. A study by Ginting (2018) also revealed that females use more lexical density than males in their descriptive writing. However, findings by Vaezi and Kafshgar (2012) showed that there was no significant difference between males and females on lexical complexity (diversity and density) in their descriptive writing.

Researchers have been studying whether there is a proficiency difference in second language learning between genders. Most research findings indicate female language learners are more proficient than their male counterparts. However, most studies have concentrated on describing the differences between students' conversational speech errors (Alhaisoni, Al-Zuoud, \& Gaudel, 2015). Bevilacqua (2017) was under the impression brain functions differ between men and women, and found language function may be more organized in women.

Although the issue of gender differences has received considerable attention in the context of second or foreign language learning and teaching, few studies on the relationship between gender and EFL learners' written errors have been carried out in China. As such, the current study has focused on the types of errors made by EFL undergraduates according to gender. 


\subsection{Undergraduates' Writing Proficiency}

Usman, Muslem, and Mustafa (2019) pointed out that one of the characteristics that contributes to differences in language learning outcomes is academic discipline, which indicates that students from different faculties may obtain difference language proficiency. According to Schmitt (2000) and Sahragard, Khajavi, and Abbasian (2016), academic discipline is related to language exposure and learning strategies, and language exposure leads to differences in vocabulary learning. Furthermore, Durrant (2016) revealed that students' from different faculties have different vocabulary knowledge and this difference affects students' reading comprehension as well as writing ability. In addition, Nation and Waring (1997) found vocabulary usage is different across different faculties.

Similarly, Peacock and Ho (2003) revealed that the use of language learning strategies is another factor that differentiates language learning across faculties. Students from social science faculties are more likely to use cognitive, compensatory, meta cognitive and social strategies, while those from natural sciences have a higher tendency to use affective strategies. However, in the research of Harish (2014), it was also found that social strategies are popular among students from natural science faculties. The contradictory results in previous studies were influenced by other variables, such as English proficiency of the research sample. There is a consensus that advanced learners use more strategies than lower level learners (Hashemi \& Hadavi, 2015; Salahshour, Sharifi, \& Salahshour, 2013).

Nancy and Day (2012) carried out a research on "how to improve the English writing levels of firstyear non-English majors". The researchers designed a series of writing courses for the students from different faculties. Moreover, they tried to improve the writing skills of students of specific faculties in a similar way by analyzing the reading and writing abilities of high-level students. The outcomes of this study provided guidelines for teachers of writing across faculties, and reflections on how to better mobilize students' reading and writing skills so as to achieve educational goals.

\section{Methodology}

This study uses the descriptive research design. The study was conducted at Hunan City University which is situated in the northern part of Hunan Province of China. The population at the university is about 4,000 students and they are non-English major students, freshmen in Hunan City University, aged between 18 to 20 years old and enrolled in the academic year 2020. Stratified random sampling was used to select 400 samples for this study.

Table-1.

Sample of the study.

\begin{tabular}{l|c|c|c|c|c}
\multirow{2}{*}{ Gender Subject } & \multicolumn{2}{c|}{ Nature Science } & \multicolumn{2}{c|}{ Social Science } & \multirow{2}{*}{ Total } \\
\cline { 2 - 6 } & $\begin{array}{c}\text { Civil } \\
\text { Engineering }\end{array}$ & $\begin{array}{c}\text { Information } \\
\text { Technology }\end{array}$ & $\begin{array}{c}\text { Chinese } \\
\text { Language Studies }\end{array}$ & $\begin{array}{c}\text { Education } \\
\text { Management }\end{array}$ & \\
\hline Male & 50 & 50 & 50 & 50 & 200 \\
\hline Female & 50 & 50 & 50 & 50 & 200 \\
\hline Total & 100 & 100 & 100 & 100 & 400 \\
\hline
\end{tabular}

Table 1 explains the details of the sample. The sample comprised 200 male and 200 female first-year non-English major undergraduates from four different faculties (Civil Engineering, Information Technology, Chinese Language Studies and Management). The researchers selected 100 undergraduates from each faculty (50 male and 50 female).

The descriptive writing test was used as the instrument to collect the quantitative data. The students were given a descriptive writing test of 350 words to be completed within 90 minutes. The students' essays were marked by a lecturer using the rubric provided by the researchers and their errors were recorded.

The 400 students' writing errors (quantitative data) was analyzed using the Statistical Package for the Social Sciences (SPSS) among which Inferential Statistics were analysed using the Independent 
Samples T-Test and Descriptive statistics were analysed through Mean and Standard Deviation. The one-way analysis of variance (ANOVA) was used to determine the significance of variation in the mean total number of writing errors in relation to the four different faculties.

\section{Results and Discussion}

RQ1. Is there a significant difference in the total number of writing errors in descriptive writing among Chinese undergraduates according to gender?

Table-2.

Comparison of the total number of writing errors between male and female students in their descriptive writings.

\begin{tabular}{l|l|l|l|l|l|l|l}
\hline Group & N & Mean & Std. Deviation & Mean Difference & t-value & df & p-value \\
\hline Male & 200 & 17.84 & 5.160 & 2.765 & 5.415 & 398 & 0.000 \\
\hline Female & 200 & 15.07 & 5.053 & & & \\
\hline
\end{tabular}

Note: Level of significance is at $\mathrm{p}<0.05$

Table 2 shows that the total number of errors for the male students is higher (Mean $=17.84$, $\mathrm{SD}=5.160$ ) than the female students (Mean=15.07, $\mathrm{SD}=5.053)$. Findings from the independent sample $\mathrm{t}-$ test showed that the female students made significantly less errors than the male students in their descriptive writings (Mean difference $=2.765, \mathrm{t}=5.415, \mathrm{df}=398, \mathrm{p}=0.000$ ). Therefore, the findings answer Research Question 1. These findings are consistent with findings by Alhaisoni et al. (2015) and Bevilacqua (2017) which stressed language function is more organized in females than males.

RQ2: Is there a significant difference in the number of mechanical errors in descriptive writing according to gender?

Table-3.

Comparison of mechanical errors between male and female students in their descriptive writings.

\begin{tabular}{l|l|c|c|c|c|c|c}
\hline Group & $\mathbf{N}$ & Mean & Std. Deviation & Mean Difference & t-value & df & p-value \\
\hline Male & 200 & 2.87 & 1.895 & 0.515 & 3.134 & 398 & 0.002 \\
\hline Female & 200 & 2.36 & 1.345 & & & \\
\hline
\end{tabular}

Table 3 shows that the mean number of mechanical errors for the male students is higher (Mean=2.87, $\mathrm{SD}=1.895$ ) than the female students (Mean=2.36, $\mathrm{SD}=1.345$ ). Findings from the independent sample t-test showed that there is a significant difference in the mean number of mechanical errors between the male and female students in their descriptive writings (Mean difference $=0.515, \mathrm{t}=3.134, \mathrm{df}=398, \mathrm{p}=0.002)$. Therefore, the findings answer Research Question 2 . These results support findings by Larsen-Freeman and Long (1991) which claimed that females are better than males in first and second language acquisition.

RQ3: Is there a significant difference in the number of coherence and cohesion errors in descriptive writing according to gender?

Table-4.

Comparison of the mean number of coherence and cohesion errors between male and female students in their descriptive writings.

\begin{tabular}{l|c|c|c|c|c|c|c}
\hline Group & N & Mean & $\begin{array}{c}\text { Std. } \\
\text { Deviation }\end{array}$ & $\begin{array}{c}\text { Mean } \\
\text { Difference }\end{array}$ & t-value & df & p-value \\
\hline Male & 200 & 3.36 & 1.236 & \multirow{2}{*}{1.130} & 10.198 & 398 & 0.000 \\
\hline Female & 200 & 2.23 & 0.964 & &
\end{tabular}

Note: Level of significance is at $\mathrm{p}<0.05$ 
Table 4. shows that the coherence and cohesion errors for the male students is higher (Mean=3.36, $\mathrm{SD}=1.236$ ) than the female students $($ Mean=2.23, $\mathrm{SD}=0.964)$. Findings from the independent sample ttest showed that there is a significant difference in the mean number of coherence and cohesion errors between the male and female students in their descriptive writings (Mean difference $=1.130, t=10.198$, $\mathrm{df}=398, \mathrm{p}=0.000$ ). Therefore, the findings answer Research Question 3. The findings of the current study indicate that male students made significantly more coherence and cohesion errors than their female counterparts. These findings are parallel with findings by Salem (2006) which indicated that females are better than males in their use of memory, cognitive and compensation strategies.

RQ4: Is there a significant difference in the number of grammatical errors in descriptive writing according to gender?

Table-5.

Comparison of the mean number of grammatical errors between male and female students in their descriptive writings.

\begin{tabular}{l|c|c|c|c|c|c|c}
\hline Group & $\mathbf{N}$ & Mean & Std. Deviation & Mean Difference & t-value & df & p-value \\
\hline Male & 200 & 3.17 & 2.559 & \multirow{2}{*}{0.590} & 2.348 & \multirow{2}{*}{398} & \multirow{2}{*}{0.019} \\
\hline Female & 200 & 2.58 & 2.465 & & & \\
\hline
\end{tabular}

Note: Level of significance is at $\mathrm{p}<0.05$.

Table 5 shows that the mean number of grammatical errors for the male students is higher (Mean=3.17, $\mathrm{SD}=2.559$ ) than the female students (Mean=2.58, $\mathrm{SD}=2.465$ ). Findings from the independent sample t-test showed that there is a significant difference in the mean number of grammatical errors between the male and female students in their descriptive writings (Mean difference $=0.590, \mathrm{t}=2.348, \mathrm{df}=398, \mathrm{p}=0.019)$. Therefore, the findings answer Research Question 4 . The current findings indicate that female students performed significantly better than male students in grammar in their descriptive writing. Errors in this area are found in word form, articles, prepositions and conjunctions. These findings are parallel with findings by Montenegro and Jankowski (2017) which indicated that females are better than males in first and second language acquisition.

RQ5: Is there a significant difference in the number of lexical errors in descriptive writing according to gender?

Table-6.

Comparison of the mean number of lexical errors between male and female students in their descriptive writings.

\begin{tabular}{c|l|c|c|c|c|c|c}
\hline Group & $\mathbf{N}$ & Mean & Std. Deviation & Mean Difference & t-value & df & p-value \\
\hline Male & 200 & 5.25 & 2.703 & 0.950 & \multirow{2}{*}{3.318} & \multirow{2}{*}{398} & 0.001 \\
\hline Female & 200 & 4.30 & 3.016 & & & \\
\hline
\end{tabular}

Table 6 shows that the mean number of lexical errors for the male students is higher $($ Mean $=5.25$, $\mathrm{SD}=2.703)$ than the female students $(\mathrm{Mean}=4.30, \mathrm{SD}=3.016)$. Findings from the independent sample ttest showed that there is a significant difference in the mean number of lexical errors between the male and female students in their descriptive writings (Mean difference $=0.950, t=3.318, \mathrm{df}=398, \mathrm{p}=0.001$ ). These findings are not consistent with findings by Vaezi and Kafshgar (2012) who found that there was no significant difference between male and female on lexical complexity (diversity and density) in their descriptive writing.

RQ6: Is there a significant difference in the number of structural errors in descriptive writing according to gender?

Table 7 shows that the mean number of structural errors for the female students is higher (Mean=3.62, $\mathrm{SD}=1.747$ ) than the male students (Mean=3.20, $\mathrm{SD}=1.907$ ). Findings from the independent sample t-test showed that there is a significant difference in the mean number of structural errors between the male and female students in their descriptive writings (Mean difference $=-0.420, t=-$ 2.297, df=398, $\mathrm{p}=0.022$ ). As such, the findings answer Research Question 6. Among the errors made by 
students in sentence structures are sentence formation, incomplete sentences, lack of proper instruction styles and failure in the proper utilization of compound and complex sentences. Therefore these findings support findings by Ginting (2018) which indicated females write with more lexical density than males in their descriptive writing.

RQ7: Is there a significant difference in the total number of writing errors in descriptive writing among Chinese undergraduates according to faculty?

Table-7.

Comparison of the mean number of structural errors between male and female students in their descriptive writings.

\begin{tabular}{l|l|c|c|c|c|c|c}
\hline Group & N & Mean & Std. Deviation & Mean Difference & t-value & df & p-value \\
\hline Male & 200 & 3.20 & 1.747 & -0.420 & -2.297 & 398 & 0.022 \\
\cline { 1 - 3 } Female & 200 & 3.62 & 1.907 & & & \\
\hline
\end{tabular}

Note: Level of significance is at $\mathrm{p}<0.05$

Table-8.

Comparison of the mean total number of writing errors among students from different faculties in their descriptive writing.

\begin{tabular}{c|c}
\hline Faculty & Mean \\
\hline Education Management & 15.53 \\
\hline Chinese Language & 15.32 \\
\hline Civil Engineering & 17.32 \\
\hline Information Technology & 17.64 \\
\hline Total & 16.45 \\
\hline
\end{tabular}

Table-9.

Results of One-way ANOVA showing writing errors among students from different faculties.

\begin{tabular}{l|c|c|c|c|c}
\hline & Sum of Squares & df & Mean Square & F & Sig. \\
\hline Between Groups & 429.628 & 3 & 143.209 & 5.293 & 0.001 \\
\hline Within Groups & 10713.470 & 396 & 27.054 & & \\
\hline Total & 11143.098 & 399 & & & \\
\hline
\end{tabular}

Note: Level of significance is at $\mathrm{p}<0.05$.

Table-10.

Results of Tukey HSD test comparing students' errors from different faculties.

\begin{tabular}{|c|c|c|c|c|c|c|}
\hline \multirow[b]{2}{*}{ (I) Faculty } & \multirow[b]{2}{*}{ (J) Faculty } & \multirow{2}{*}{$\begin{array}{c}\text { Mean } \\
\text { Difference } \\
(\mathbf{I}-\mathbf{J})\end{array}$} & \multirow[b]{2}{*}{$\begin{array}{c}\text { Std. } \\
\text { Error }\end{array}$} & \multirow[b]{2}{*}{ Sig. } & \multicolumn{2}{|c|}{ 95\% Confidence Interval } \\
\hline & & & & & $\begin{array}{l}\text { Lower } \\
\text { Bound }\end{array}$ & Upper Bound \\
\hline \multirow{3}{*}{$\begin{array}{l}\text { Education } \\
\text { Management }\end{array}$} & Chinese Language & 0.210 & 0.736 & 0.992 & -1.69 & 2.11 \\
\hline & Civil Engineering & -1.790 & 0.736 & 0.073 & -3.69 & 0.11 \\
\hline & Information Technology & $-2.110^{*}$ & 0.736 & 0.022 & -4.01 & -0.21 \\
\hline \multirow[t]{3}{*}{ Chinese Language } & Education Management & -0.210 & 0.736 & 0.992 & -2.11 & 1.69 \\
\hline & Civil Engineering & $-2.000^{*}$ & 0.736 & 0.034 & -3.90 & -0.10 \\
\hline & Information Technology & $-2.320^{*}$ & 0.736 & 0.009 & -4.22 & -0.42 \\
\hline \multirow[t]{3}{*}{ Civil Engineering } & Education Management & 1.790 & 0.736 & 0.073 & -0.11 & 3.69 \\
\hline & Chinese Language & $2.000^{*}$ & 0.736 & 0.034 & 0.10 & 3.90 \\
\hline & Information Technology & -0.320 & 0.736 & 0.972 & -2.22 & 1.58 \\
\hline \multirow{3}{*}{$\begin{array}{l}\text { Information } \\
\text { Technology }\end{array}$} & Education Management & $2.110^{*}$ & 0.736 & 0.022 & 0.21 & 4.01 \\
\hline & Chinese Language & 2.320* & 0.736 & 0.009 & 0.42 & 4.22 \\
\hline & Civil Engineering & 0.320 & 0.736 & 0.972 & -1.58 & 2.22 \\
\hline
\end{tabular}

Note: *. The mean difference is significant at the 0.05 level. 
Table 8 shows that the overall mean errors of the 400 students is 16.45 . As for the writing errors in the four faculties, the students from the faculty of Chinese Language Studies made the least number of errors in their writings (Mean=15.32), followed by the students from the faculty of Education Management (Mean=15.53) and Civil Engineering (17.32). The students from the faculty of Information Technology made the most number of errors in their writings (Mean=17.64). Table 9 shows the results of One-way ANOVA which indicate that there is a significant difference in the mean errors among the students from the four different faculties $(\mathrm{df}=3, \mathrm{~F}=5.293, \mathrm{p}=0.001)$.

Findings in Table 10 reveal that there is a significant difference in writing errors in descriptive writing between the faculty of Education Management and Information Technology $(p=0.022)$, Chinese Language Studies and Civil Engineering $(\mathrm{p}=0.034)$, and also Chinese Language Studies and Information Technology $(\mathrm{p}=0.009)$. Therefore, the findings clearly indicate that there is a significant difference in the mean of writing errors among students from different faculties. These findings are consistent with the findings by Usman et al. (2019) who pointed out that students from different faculties obtain different language proficiency. Moreover, their findings also indicated that the students from the faculties of social science significantly outperformed their counterparts from the faculties of natural sciences. As stressed by Peacock and Ho (2003), students from Faculty of Chinese Language Studies and Education Management made minimum errors because they have better writing strategies than students from the Information Technology and Civil Engineering faculties.

\section{Conclusion}

The findings of the quantitative data of the current study reveal that female students made significantly less errors than their male counterparts in the overall number of errors as well as in mechanics, coherence and cohesion, grammar, lexical items and structure. This study also indicates that students from different faculties perform differently in their descriptive writings. Students from the Faculty of Chinese Language Studies and Education Management made significantly less errors than the students from the Information Technology and Civil Engineering faculties.

In terms of theoretical implications, the findings indicate that students made most errors in lexical items, followed by coherence and cohesion, structure, grammar and mechanics. These findings are in accordance with the 'Model of Errors' proposed by James (2013) in which he also highlighted the same types of errors (mechanics, grammar, coherence and cohesion, lexical items and structure).

Moreover, these findings also have strong pedagogical implications for EFL lecturers in the colleges and universities of China. The findings suggest that EFL lecturers should employ appropriate pedagogy to minimize male students' errors in their writing. Based on these results, lecturers should also utilize effective methods to improve the male students' English writing skills. In addition, ESL lecturers should adopt creative and different teaching strategies while teaching students from different faculties because they tend to show different results in their descriptive writings.

It is also important to note that there are limitations in the study. First of all, the sample size of this study only consisted of 400 undergraduates from one Chinese university. As such, it is hoped that future studies will involve a larger sample from different universities in other provinces of China. In addition, this study only analyzed one genre of writing, which is descriptive writing. In order to obtain more comprehensive data on students' writing errors, it is suggested that future researchers may conduct similar studies on other genres of writing, such as argumentative writing, narrative writing, and factual writing. Moreover, this research only pointed out that there are significant differences in the writing ability of students from different faculties but it did not specifically analyze the cause of students' writing errors. In addition, it is suggested that future researchers can conduct quasi-experimental studies on the effectiveness of utilizing the process approach and the product approach to minimize students' errors in writing and improve their writing skills. It is also hoped that future researchers will design ESL writing courses for students from different faculties to minimize students' errors and enhance their writing skills. 


\section{References}

Alhaisoni, E. M., Al-Zuoud, K. M., \& Gaudel, D. R. (2015). Analysis of spelling errors of Saudi beginner learners of English enrolled in an intensive English language program. English Language Teaching, 8(3), 185-192. Available at: https://doi.org/10.5539/elt.v8n3p185.

Bevilacqua, A. (2017). Commentary: Should gender differences be included in the evolutionary upgrade to cognitive load theory? Educational Psychology Revierw, 29(1), 189-194. Available at: https://doi.org/10.1007/s 10648-016-9362-6.

Boroomand, F., \& Rostami Abusaeedi, A. (2013). A gender-based analysis of Iranian EFL learners' types of written errors. International Journal of Research Studies in Language Learning, 2(5), 79-92. Available at: https://doi.org/10.5861/ijrsll.2013.287.

Chiu, C. (2008). An investigation of gender differences in EFL college writing. Paper presented at the Proceedings of the BAAL Annual Conference 2008.

Christine, C. T. (2016). Subsumable relationship among error types of EFL Writers: A learner corpus-based study of expository writing at the intermediate level. English Teaching and Learning, 4O(1), 113-151.

Corder, S. (1967). The significance of learners' errors. International Review of Applied Linguistics, 5(4), 161-169.

Corder, S. P. (1981). Error analysis and interlanguage (pp. 125). Oxford: Oxford University Press.

Corona, R., Rodríguez, V. M., McDonald, S. E., Velazquez, E., Rodríguez, A., \& Fuentes, V. E. (2017). Associations between cultural stressors, cultural values, and Latina/o college students' mental health. Journal of Youth and Adolescence, 46(1), 63-77.

Cumming, A. (2003). Experienced ESL/EFL writing instructors' conceptualizations of their teaching: Curriculum options and implications. In B. Kroll (ed.), Exploring the dynamics of second language writing (pp. 71-92). New York: Cambridge University Press.

Dingwall, W. O. (1998). The biological bases of human communication behavior. In J. B.Gleason \& N. B. Ratner (Eds.), Psycholinguistics (pp. 51-105). Fort Worth: Harcourt Brace College Publishers.

Divsar, H., \& Heydari, R. (2017). A corpus-based study of EFL learners' errors in IELTS essay writing. International Journal of Applied Linguistics and English Literature, 6(3), 143-149. Available at: https://doi.org/10.7575/aiac.ijalel.v.6n.3p.143.

Dulay, H. C., Burt, M. K., \& Krashen, S. D. (1982). Language two. Rowley, MA: Newbury House.

Durrant, P. (2016). To what extent is the Academic Vocabulary List relevant to university student writing? English for Specific Purposes, 43, 49-61. Available at: https://doi.org/10.1016/j.esp.2016.01.004.

Ginting, S. A. (2018). Syntactic complexity on extroverted and introverted Indonesian language learners' written products. International Journal of Education and Literacy Studies, 6(4), 101-106. Available at: https://doi.org/10.7575/aiac.ijels.v.6n.4p.101.

Gray, S. S. (2013). Framing "at risk" students: Struggles at the boundaries of access to higher education. Children and Youth Services Review, 35(8), 1245-1251. Available at: https://doi.org/10.1016/j.childyouth.2013.04.011.

Harish, S. (2014). Social strategy use and language learning contexts: A case study of Malayalee undergraduate students in India. System, 43(1), 64-73. Available at: https://doi.org/10.1016/j.system.2014.01.002.

Hart Research Associates. (2015). ringing equity and quality learning together: Institutional priorities for tracking and advancing underserved students' success. Key findings from a survey and in-depth interviews among administrators at AACEU member Institutions. Washington, DC: Association of American Colleges and Universities.

Hashemi, Z., \& Hadavi, M. (2015). Investigation of vocabulary learning strategies among EFL Iranian medical sciences students. Procedia-Social and Behavioral Sciences, 192, 629-637. Available at: https://doi.org/10.1016/j.sbspro.2015.06.110.

James, C. (1998). Errors in language learning and use: Exploring error analysis. New York: Rouledge.

James, C. (2013). Errors in language learning and use: Exploring Error Analysis. New York: Routledge.

Kelly-Riley, D. (2015). Toward a validational framework using student course papers from common undergraduate curricular requirements as viable outcomes evidence. Assessing Writing, 23, R713-R715. Available at: ps://doi.org/10.1016/j.cub.2017.05.064.

Khurshid, F., \& Mahmood, N. (2012). Learning styles of natural sciences, social sciences and humanities students at graduate level. Interdisciplinary Journal of Contemporary Research in Business, 3(9), 672-678.

Larsen-Freeman, D., \& Long, M. (1991). An introduction to second language acquisition research. London: Longman.

Mohammed, B. I. (2014). Error analysis of passive transformation and its pedagogical Implications: A case study of selected Bura learners of English. Doctoral dissertation, Ahmadu Bello University, Zaria.

Montenegro, E., \& Jankowski, N. A. (2017). Equity and assessment: Moving towards culturally responsive assessment. Urbana, IL: University of Illinois and Indiana University, National Institute for Learning Outcomes Assessment (NILOA).

Nancy, N., \& Day, K. (2012). Using undergraduates' digital literacy skills to improve their discipline-specific writing: A dialogue. International Journal for the Scholarship of Teaching and Learning, 6(2), n2. Available at: https://doi.org/10.20429/ijsotl.2012.060205.

Nation, P., \& Waring, R. (1997). Vocabulary size, text coverage and word lists. In N. Schmitt \& M. McCarthy (Eds.), Vocabulary: Description, Acquisition and Pedagogy (pp. 6-20). Cambridge: Cambridge University Press.

Peacock, M., \& Ho, B. (2003). Student language learning strategies across eight disciplines. International Journal of Applied Linguistics, 13(2), 179-200. Available at: https://doi.org/10.1111/1473-4192.00043. 
Richards, J. C., \& Schmidt, R. (2002). Dictionary of language teaching and applied linguistics. London: Longman.

Sahragard, R., Khajavi, Y., \& Abbasian, R. (2016). Field of study, learning styles, and language learning strategies of university students: Are there any relations? Innovation in Language Learning and Teaching, 10(3), 255-271. Available at: https://doi.org/10.1080/17501229.2014.976225.

Salahshour, F., Sharifi, M., \& Salahshour, N. (2013). The relationship between language learning strategy use, language proficiency level and learner gender. Procedia-Social and Behavioral Sciences, 70, 634-643. Available at: https://doi.org/10.1016/j.sbspro.2013.01.103.

Salem, N. M. (2006). The role of motivation, gender, and language learning strategies in EFL proficiency. Unpublished thesis. American University of Beirut.

Schmitt, N. (2000). Vocabulary in language teaching. Cambridge: Cambridge University Press.

Usman, K., Muslem, A., \& Mustafa, F. (2019). Differences in English proficiency test scores between students of social and natural sciences. International Journal of Instruction, 12(1), 479-492. Available at: https://doi.org/10.29333/iji.2019.12131a.

Vaezi, S., \& Kafshgar, N. B. (2012). Learner characteristics and syntactic and lexical complexity of written products. International Journal of Linguistics, 4(3), 671-687. Available at: https://doi.org/10.5296/ijl.v4i3.2391.

Voyer, D., \& Voyer, S. D. (2014). Gender differences in scholastic achievement: A meta-analysis. Psychological bulletin, 140(4), 1174-1204. Available at: https://doi.org/10.1037/a0036620.

Zafar, A. (2016). Error analysis: a tool to improve English skills of undergraduate students. Procedia-Social and Behavioral Sciences, 217, 697-705. Available at: https://doi.org/10.1016/j.sbspro.2016.02.122.

Contemporary Research in Education and English Language Teaching

ISSN: 2641-0230

Vol. 3, No. 2, pp. 21-30, 2021

DOI: $10.33094 / 26410230.2021 .32 .21 .30$

(C) 2021 by the authors; licensee Learning Gate 